\title{
THE WALTZ'S THIRD LEVEL OF ANALYSIS AND CHINA'S PURSUIT OF LEGITIMACY VIA THE AIIB ${ }^{1}$
}

\begin{abstract}
Nuruddin Abdul Aziz
Abstract: Since 2016, the Asian Infrastructure and Investment Bank (AIIB) has assisted countries to improve their economic conditions with infrastructure and transport projects. Publicly proposed in 2013 by China's President, Xi Jinping during his state visit to Indonesia, the AIIB has helped consolidate China's legitimacy as a leading power in Asia and globally. Thus, this paper argues that forming the AIIB was a move to counter the relatively low vote share in the neoliberal's international financial institutions, namely the World Bank, the International Monetary Fund (IMF), and the Japan-led Asian Development Bank (ADB). With the added benefit of leading a development institution, more legitimacy is gained via the international system. Since its establishment, AIIB has significantly increased from 57 founding members in 2016 to 103 in 2020. In examining how this translates into China gaining legitimacy from the international system, this paper examined the case of China's AIIB through the Third Level of Analysis in Kenneth Waltz's Neorealism. In his The State, And War, Waltz argued for the "Levels of Analysis" and convinced the third level analyses a state's legitimacy and goals via the international system's responses and interactions. This paper examined the relationship between China's standing in the eyes of the world and the acceptance of AIIB as a legitimate development institution.
\end{abstract}

Keywords: AIIB, China, third level of analysis, multilateral development institutions, International Infrastructure investment,

\section{INTRODUCTION}

In another bid to strengthen its position as a leading global and regional power, China initiated Asian Infrastructure and Investment Bank (AIIB) in 2014. China's move to formalize the AIIB met with opposition from the United States, who was concerned with the rise of China.

Japan, a China's long-time rival, former regional hegemon, and firm ally to the U.S., also opposed $^{3}$. Both opposing states are unsurprisingly not the members of the multilateral development bank. It is interesting to observe China's behaviour in the face of such disapproval from its rivals on the global, regional stage. Beijing's decisions in this issue can be better understood by analysing the three levels which inform and guide a state towards a particular foreign policy. They are individual level, domestic level, and structural level.

This article focuses on the structural level or the third level of analysis. More specifically, the central focus of the discussion will be on the concepts of material and ideational structures within the context of the third level of analysis. The concepts presented within this level of analysis as argued by

\footnotetext{
${ }^{1}$ Article info: Received: 27 September 2021; Acceptance: 28 October 2021; Published: 15 December 2021.

${ }^{2}$ Author: Nuruddin Abdul Aziz, a Lecturer at the International Relations Program, School of Business and Management, Asia Pacific University, Kuala Lumpur, Malaysia. Email: nuruddin.aziz@staffemail.apu.edu.my

${ }^{3}$ Saori N. Katada and Jessica Liao, "China and Japan in Pursuit of Infrastructure Investment Leadership in Asia: Competition or Convergence?” Global Governance 26, no. 3, (2020): 463.
} 
relevant scholars will also be detailed in this first part. Secondly, the concepts will be applied in explaining China's persistence and role in establishing the AIIB. In this second part, concepts such as material power, ideational structures, social mechanisms, and polarity will be used as this paper attempts to unpack China's decision making vis-à-vis its role in the establishment and the administration of the AIIB.

\section{THE RISE OF CHINA: THE FIRST AND SECOND LEVEL OF ANALYSIS}

Before delving more into the specifics of the third level, it is important to look back at the two previous levels of analysis, the individual and the state level. The individual-level looks at the behaviour of states as the extensions of behaviour, personality, and beliefs of the individual that leads the state. Varied personalities among world leaders mean that the differences in state behaviour in international relations are a given. To this point, Byman and Pollack argue that the heads of state cannot be viewed as the 'straw men' and not all of them are by default "aggressive, greedy, or war-seeking". 4

Let us briefly look at the first level of analysis regarding China's recent behaviour. Xi Jinping, since taking office as the President of China in 2012, has come to represent the 'China Dream', an idea that sees modern China as one of the leading global powers and restored to its past glories of the dynastic era. ${ }^{5}$ Having shaped himself as the saviour of Chinese traditions and culture, Mr. Xi has formulated his foreign policy agenda to be more forceful and assertive. ${ }^{6}$ One can argue that one of China's more assertive foreign policy directions, which includes claiming large parts of international waters in the South China Sea as part of its territory, extends Xi's personality. Chinese vessels can be ruthless when dealing with Filipino ships that they deem to have encroached on Chinese waters. Such an approach is not unlike what Xi himself would practise, as his crackdowns on dissent and corruption in his country have evidenced. ${ }^{7}$

The second level of analysis concerns with the state or domestic determinants behind a state's foreign policy. The determinants, in this case, include the type of government, political parties operating within the state, the local media, and local civil society groups. Collectively or independently, they may sway their government's foreign policy in one way or another. Steven Friedman provides instances where interest groups and civil society came together in Brazil, Thailand, and Sri Lanka to try and influence their respective government's actions on the international stage, to varied levels of success. ${ }^{8}$

We must look at the domestic factors within the state of China to further explain its behaviour. The political system is arguably the most significant domestic determinant behind China's foreign policy. This is a system cantered on the Chinese Communist Party (CCP) and is structured to place the CCP as the ultimate authority in making decisions. With the country's large population on the leaders' minds, a situation where civil uprising can flare up at any moment would not be ideal. ${ }^{9} \mathrm{Mr} \mathrm{Xi}$ has also

\footnotetext{
${ }^{4}$ Daniel L. Byman and Kenneth M. Pollack, "Let Us Now Praise Great Men: Bringing the Statesman Back In," International Security 25, no. 4, (2001): 109.

${ }^{5}$ Axel Berkofsky, "The Chinese Dream and Chinese Foreign and Security Policies: Rosy Rhetoric versus Harsh Realities," Asia-Pacific Review 23, no. 2, (2016): 110.

6 Ian Johnson, "Xi Jinping and China's New Era of Glory," The New York Times, 13 October 2017, https://www.nytimes.com/2017/10/13/sunday-review/xi-jinping-china.html

${ }^{7}$ Willy Wo-Lap Lam, “The Agenda of Xi Jinping in the Chinese Communist Party: Capable of Through Reform?” in Willy Wo-Lap Lam ed., Routledge Handbook of the Chinese Communist Party, (London, Routledge, 2018), 19.

${ }^{8}$ Steven Friedman, "The Forgotten Sovereign: Citizens, States and Foreign Policy in the South," in Maurice A. East and Justin Robertson eds., Diplomacy and Developing Nations: Post-Cold War Foreign Policy-Making Structures and Processes, (3rd edition), (London, Routledge, 2012), 230.

${ }^{9}$ Susan Shirk. "The Domestic Context of Chinese Foreign Security Policies," in Sadia M. Pekkanen, John Ravenhill, and Rosemary Foot, eds., The Oxford Handbook of the International Relations of Asia, (Oxford, Oxford University Press, 2014), 40 .
} 
consolidated his power within the CCP, further disallowing dissent among the party members. ${ }^{10}$ The leadership of China has conveyed its recent ascent and vision to the Chinese people, and they in turn experience a surge of nationalism and pride, which the leadership subsequently capitalizes on and uses to justify their actions on the world stage as the 'will of the people'. ${ }^{11}$ It can also be viewed as a selffulfilling prophecy on the part of the Chinese leadership.

With the essential elements of the previous levels of analysis summarised and how they relate to China is explained, let us now look at the third level of analysis, which examines the international structure as a factor in states' behaviour.

\section{THE THIRD LEVEL OF ANALYSIS}

For realists like Waltz, the international structure is anarchic in nature, and thus powerful states will be forced into finding a balance of power to counter any potential conflicts arising from unequal power distribution. ${ }^{12}$ This viewpoint considers war as a constant possibility, especially when there are two or more states competing to project themselves as the strongest power and promote their own national interests. ${ }^{13}$

Today, with international rules and norms already established, along with international organizations and bureaucracies that enforce and regulate them, one could argue that all foreign policies can be analysed without looking at the characteristics of the states and the individuals who lead them. The international system influences countries to behave the way they behave based on how much power they have relative to other states. Scholars like Paul Wohlforth call these great powers as 'poles' and use this term to further explain the great power political systems using the concept of different types of polarity which are unipolarity, bipolarity, and multipolarity. ${ }^{14}$ Polarity is used to explain the international system in terms of powerful states existing at any point in time; how many there are, how powerful they are, and how these powerful states organise; directly or indirectly, the hierarchy in the international system.

A pole is described as a state having a large deposit of material resources - economic, natural, and human - to carry out its needs. A pole also possesses clear advantages over the majority of states in terms of the quantity, quality, and importance of its military. Excelling in all these elements, or having preponderance in military, state, and economic capabilities, is the goal of powerful states according to realist view. ${ }^{15}$

\section{MATERIAL STRUCTURES \& TYPES OF POLARITY}

The most recent point in history where the international system existed in a state of multipolarity is in the mid- $19^{\text {th }}$ century period where five great powers, Britain, Russia, Prussia, France, and the House of Hapsburg, were more or less equal in terms of capability in all the aspects mentioned above. ${ }^{16}$ As a multipolar world does not have a clear-cut hierarchy, and no state is unambiguously dominant, status competition happens more frequently. ${ }^{17}$ Wohlforth opines that a multipolar world is one where

\footnotetext{
${ }^{10}$ Chris Ogden, A Dictionary of Politics, and International Relations in China, (Oxford, Oxford University Press, 2018), 12 Mark Lanteigne, Chinese Policy: An Introduction (4th edition), (London, Routledge, 2020), 37.

${ }^{11}$ Rosemary Foot, "China and the Tiananmen Crisis of June 1989," in Steve Smith, Amelia Hadfield, and Tim Dunne, eds., Foreign Policy: Theories, Actors, Cases (3rd edition), (Oxford, Oxford University Press, 2017), 341.

${ }_{12}$ Kenneth Waltz, Man, The State, And War, (New York, Columbia University Press, 1979), 57.

13 Ibid., 60.

${ }_{14}$ William C. Wohlforth, “Unipolarity, Status Competition, and Great Power War,” World Politics 61, no. 1, (2009): 28.

${ }_{15}$ Kenneth Waltz, Man, The State, And War, (1979), 57.

${ }^{16}$ William C. Wohlforth, "Unipolarity, Status Competition, and Great Power War," (2009): 29.

${ }^{17}$ William C. Wohlforth Ibid., (2009): 31.
} 
periodic struggles, including armed conflict, among the poles occur in order to advance their self-

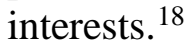

From multipolarity, the world saw a shift in great power politics post-World War II. The United States and the Soviet Union had substantial power and played the other side up as the ideologically inferior state. This state of bipolarity in the world meant that a hierarchy was beginning to make itself visible to observers. It had the U.S. and USSR at the top, with second-tier major powers of the time comparing themselves to the two poles, some even acting as their proxies. Even if the second-tier powers were to feel aggrieved by actions taken by the poles, they would not resort to conflict but rather find more creative solutions to solve the issue. ${ }^{19}$

The end of the Cold War saw the world shift to a unipolar order. The United States as the sole superpower left standing after the fall of the Berlin Wall would embark on a path with foreign policy decisions taken to "maintain U.S. predominance". ${ }^{20}$ In terms of nuclear capability, the U.S. has continued to pump in billions into its nuclear programs to ensure its supremacy in this aspect. Its presence is visible in almost every region on earth even with no clear equal or rival. The biggest spenders in defense, it also operates military bases in the countries of their allies, watching over their interests, while serving their secondary purpose of providing military protection for these allies should a hostile nation attack. ${ }^{21}$

\section{IDEATIONAL STRUCTURES AND SOCIAL MECHANISMS}

In the years following the end of the Cold War, social constructivist scholars began examining the social and ideational structures of the international system. To them, desired social effects on the world's population is difficult to achieve with only advantages in material power. ${ }^{22}$ With norms regarding sovereignty and war already well-established in 1990s, simply having preponderance in all the material indicators of power was not enough for the number one power in a unipolar system. This point of view, also called the ideational structure viewpoint, provides a constructivist alternative to the material ways to look at power which comes from a realist standpoint.

Within the ideational structure, three social mechanisms exist that, according to Martha Finnemore, "limit unipolar power and shape its possible uses". ${ }^{23}$ The first one involves the unipole legitimising its power and actions in the international arena. To do this, the unipole must first recognize the power and roles of other states in the international system, as legitimation must be earned from others. The second one is the process of institutionalising unipolar power. This can take the form of establishing legal authorities, international bureaucracies, and laws and norms. Unipoles can shape these institutions to suit their own needs. The third involves hypocrisy. Institutionalising international laws and norms that are binding can sometimes present a dilemma for a unipole when it feels that these laws and norms get in the way of them achieving their interests. ${ }^{24}$ Therefore, the unipole may resort to violating these laws and norms which oftentimes had profound impacts on its legitimacy and how other states view its power.

\footnotetext{
${ }^{18}$ William C. Wohlforth, Ibid., 34.

${ }^{19}$ David C. Kang, "Hierarchy, Balancing, and Empirical Puzzles in Asian International Relations," International Security 28, no. 3, (2003): 58 .

${ }^{20}$ David C. Kang, Hierarchy, Balancing, and Empirical Puzzles in Asian International Relations,” (2003): 59.

${ }^{21}$ Stephan Haggard, "The Balance of Power, Globalization, and Democracy: International relations Theory in Asia," Journal of East Asian Studies 4, no. (2004): 12-13.

${ }^{22}$ Alexander Wendt, "Anarchy is what States Make of It: The Social Construction of Power Politics," International Organization 46, no. 2, (1992): 392.

${ }^{23}$ Martha Finnemore, “Legitimacy, Hypocrisy, and the Social Structure of Unipolarity: Why Being a Unipole Isn’t All It's Cracked Up to Be," World Politics 61, no. 1, (2009): 62.

${ }^{24}$ Martha Finnemore, "Legitimacy, Hypocrisy, and the Social Structure of Unipolarity: Why Being a Unipole Isn't All It's Cracked Up to Be," (2009): 65.
} 
It seems that the United States felt somewhat threatened by the recent growth of China's influence over East Asia. The establishment of the AIIB is the latest of Chinese initiatives that has got Washington watching very closely. ${ }^{25}$ It could be said that with all the infrastructure investment in developing countries, aggressive claiming of territorial waters, and taking the lead in multilateral institutions, China is acting like a unipole within the Asian region. The legitimation it sought from members of the AIIB, as well as institutionalising it, are seen as unipolar actions and thus need to be analysed from a third level perspective to further understand them.

\section{THIRD LEVEL ANALYSIS OF CHINA'S BEHAVIOUR AND THE AIIB - MATERIAL \& IDEATIONAL STRUCTURES}

Now let us properly analyse China's pursuit of the AIIB. As its economic and military power grow, it is already evident that China has enough material power to compete with, and even beat other powers in Asian region. ${ }^{26}$ These advantages over rivals like Japan have spurred China on towards strengthening its claim as the unipole in Asia through utilizing the ideational and social structures of world politics. By dominating the conversations on international norms and rule setting vis-à-vis multilateral institutions like the AIIB, Beijing will have the legitimacy it seeks.

Legitimation is one of the social mechanisms mentioned by Finnemore which big powers apply in shaping their power and influence. ${ }^{27}$ By courting some of the world's strongest economies to join the AIIB, China aimed to gain legitimacy from the world community by being perceived as a capable leader of the likes of the United Kingdom, France and Germany. ${ }^{28}$ The inclusion of South Korea and Australia also shows that regional rivalries and allegiances to the U.S. could be put aside for mutual benefits, and further added to the idea of Chinese legitimacy.

With 57 states now as members of the AIIB, Washington has backtracked on its criticism and has now expressed new support and suggested that there could be a collaboration between AIIB and other Washington consensus institutions. ${ }^{29}$ This has arguably been the biggest boost to China's legitimacy vis-à-vis the AIIB. It just shows that with persistent positive interactions with states that are known to be looking for alternative pathways for better infrastructure development, more of them will join the cause and the case for opposition against it will become weaker. In the case of getting the Philippines to join the AIIB, the task was already complicated with this state standing to lose the most if China were to get its way in claiming the contested territories in the South China Sea. As one of Washington's closest allies in the region, there would of course be some resistances to Manila joining the AIIB. A change in Filipino leadership and findings that suggested China could help alleviate some of the Philippines' problems, such as the overcrowding of the Port of Manila, forced a rethink and the Philippines eventually joined. ${ }^{30}$

Joining the AIIB does not mean the Philippines agrees with China's territorial claims, in fact, far from it. Finance Secretary Cesar Purisima remarked that the AIIB should not be used to give China an advantage in the issue. ${ }^{31}$ Recognizing a state's legitimacy as the central authority in a multilateral

\footnotetext{
${ }^{25}$ Jiejin Zhu, "Is the AIIB a China-controlled Bank? China's Evolving Multilateralism in Three Dimensions (3D)," Global Policy 18, no. 4, (2019): 654.

${ }^{26}$ Friso M. S. Stevens, "China's Long March to National Rejuvenation: Toward a Neo-Imperial Order in East Asia?," Asian Security 17, no. 1, (2021): 47.

${ }^{27}$ Martha Finnemore, “Legitimacy, Hypocrisy, and the Social Structure of Unipolarity: Why Being a Unipole Isn't All It's Cracked Up to Be," (2009): 61.

${ }^{28}$ Xiao Ren, "China as an Institution-Builder: The Case of the AIIB," The Pacific Review 29, no. 3, (2016): 436.

${ }^{29}$ Shahar Hameiri and Lee Jones, "China Challenges Global Governance? Chinese International Development Finance and the AIIB," International Affairs 94, no. 3, (2018): 436.

${ }^{30}$ Yu Wang, "The Political Economy of Joining the AIIB," The Chinese Journal of International Politics, 11, no. 2, (2018): 109.

${ }^{31}$ Miran Park, "China-led AIIB as a Gradual Modification of Asian Financial Order," Chinese Strategies to Launch New Financial Institution,” Journal of International and Area Studies, 24, no. 2, (2017): 59.
} 
institution is not a wide acceptance of the state's policies. However, it does imply a tacit acceptance of the social structure of power and hierarchies. ${ }^{32}$ It is akin to accepting a veto decision from a P5 member of the UN Security Council despite having objections to P5 members' positions. Thus, legitimacy is still given by the smaller state to the more powerful state despite unresolved differences. Legitimacy in this case was definitely earned and not given. 30 more states including Canada would later express interest in joining the AIIB and this further strengthened China's legitimacy as a rising global power and AIIB's legitimacy as a significant multilateral institution. ${ }^{33}$ While on March 19, 2018, this legitimacy was sealed on paper when the North American country would officially join the investment bank and started serving on the AIIB's Board of Directors in July that year. ${ }^{34}$

The period between the MOU signing on the bank by the initial 20 member states in October 2014 and the start of the bank's operation in December 2015 was used to negotiate the bank's structure and administration.35 Finnemore describes this process as institutionalisation. 36 It is essentially a legitimation strategy, where organisations, rules, and laws are established by the unipole to shape and also limit their power.37 Usually this power is diffused through rational-legal authorities such as the UN Security Council or Asian Development Bank (ADB). Japan, as the previous unipole in the region, benefitted from the structure of ADB, a Japan-directed body, where it controlled a $12.8 \%$ votes that when combined with the total vote share of other OECD member states, brings it up to $58 \% .38$ Institutionalisation is the process where power is transformed into authority with mechanisms such as vote shares, veto powers, and bureaucracy made into law.39 Sometimes, this may benefit the unipole in its quest for more power, but there are instances where this can limit the unipole's power and check it.

As for mechanisms that are present within the AIIB, the voting power ("shareholding" in AIIB terminology) is in favour of China. It holds $26.06 \%$ of voting power, which is just over the $25 \%$ required to block any decisions requiring a super majority vote (defined by the bank's articles of agreement to be three-fourths of the voting power and two-thirds of the members). 40 This veto power is justified by the fact that China contributes the most capital to the bank, therefore making it the largest shareholder in the AIIB.41 After years of being given a vote share in other MDBs that it felt did not match the size of its economy, China had institutionalised a system which bounds its members by a set of legalities, procedures, and norms that made it seem like an egalitarian system but in fact it was not. The shareholder voting power ultimately makes China the state with the final say in most cases within the AIIB.

\footnotetext{
${ }^{32}$ Martha Finnemore, "Legitimacy, Hypocrisy, and the Social Structure of Unipolarity: Why Being a Unipole Isn't All It's Cracked Up to Be," (2009): 62.

${ }^{33}$ Alice Ba, "In Pursuit of Asian Infrastructure and Investment Bank: The Politics and Geopolitics of a Chinese Bank," in Steven B. Rothman, Utpal Vyas, and Yoichiro Sato eds., Regional Institutions, Geopolitics and Economics in the AsiaPacific: Evolving Interests and Strategies, (New York, Routledge, 2017), 39.

${ }^{34}$ Kristin Huang, "China-Canada Ties to Get Frostier After Call to Leave AIIB, Analysts Say," South China Morning Post, 12 December 2019, https://ph.news.yahoo.com/china-canada-ties-frostier-call-105718228.html

${ }^{35}$ Alice Ba, "In Pursuit of Asian Infrastructure \& Investment Bank: The Politics and Geopolitics of a Chinese Bank," (2017): 40.

${ }^{36}$ Martha Finnemore, “Legitimacy, Hypocrisy, and the Social Structure of Unipolarity: Why Being a Unipole Isn't All It's Cracked Up to Be," (2009): 64.

${ }^{37}$ See also Jeffrey T. Checkel, "The Constructivist Turn in International Relations Theory," World Politics 50, no. 2 , (1998): 324-348.

${ }^{38}$ Alice Ba, "In Pursuit of Asian Infrastructure \& Investment Bank: The Politics and Geopolitics of a Chinese Bank," (2009): 42.

${ }^{39}$ Alice Ba, Ibid., 69.

${ }^{40}$ Scott Morris and Mamoru Higashikokubaru, "Doing the Math on AIIB Governance," Center for Global Development, 2 July 2015, https://www.cgdev.org/blog/doing-math-aiib-governance

${ }^{41}$ Mathew D. Stephan and David Skidmore, “AIIB in the Liberal International order," Chinese Journal of International Politics 12, no. 1, (2019): 65.
} 
The issue of whether there is Chinese hypocrisy in setting up the AIIB is trickier to analyse as the bank was only established five years ago. Is it a hypocritical decision to invite Vietnam, Indonesia, Malaysia and the Philippines into the bank considering the competing claims China has with these countries over the South China Sea? On the surface, it seems not. The AIIB at the offset focuses mainly on infrastructure and presents a more innovative and streamlined governance structure. ${ }^{42}$ It does not include solving border disputes as part of its agenda. According to Finnemore, a unipole committing hypocrisy in the context of ideational structures has 3 elements: its actions are at odds with its proclaimed values, alternative actions are available, and that it is likely trying to deceive others about the mismatch between its actions and values. ${ }^{43}$

Unlike the United States, China has not publicly conveyed what values and systems it hopes to see in the world. Think of the U.S.'s constant promotion of human rights, democracy and elections all across the world. It would be hypocritical for Washington to act against these values if situations arise that do not serve their interests. But as history has evidenced, the U.S. has had a hand in removing legitimately elected governments in Iran, Chile, Guatemala, and Nicaragua, acts undoubtedly at odds with its democracy promotion. ${ }^{44}$ In response to the Islamist party Hamas gaining victory in the Gaza Strip during the 2006 Palestinian elections, the U.S. cut off direct aid to the Palestinian Authority. As China has not made democracy promotion one of its core foreign policy tenets, its infrastructure development projects in repressive countries such as Cambodia and Myanmar are put under less scrutiny. In fact, even as the more established institutions, World Bank and ADB, are putting operations on hold as violence in post-coup Myanmar rages on, AIIB has signalled that it is ready to continue its projects there to lend to Myanmar's ruling military junta, also known as the State Administration Council, adding to $\$ 20$ million that it has already contributed for a power plant. ${ }^{45}$ Joachim von Amsberg, AIIB's vice president, stated that his organisation could possibly lend to the junta under a "de facto government" framework and further elaborated that one particular country's "form of government" does not factor into decisions made regarding the said country. ${ }^{46}$ It remains to be seen whether China will have to resort to hypocrisy or not in its tenure as the lead shareholder in the AIIB.

\section{SYSTEMIC CHALLENGES TO AIIB'S LEGITIMACY MOVING FORWARD}

China's increased economic and military capabilities, and rapid growth compared to its regional rivals have put it in a strong position as the leading power in Asia. In analysing its pursuit of establishing the AIIB as a better alternative to the Japan-led ADB and the Washington Consensus MDBs, the third level of analysis provides the best explanations of its actions and behaviour. The lack of a clear rival in the region has essentially made China the unipole of Asia. As the unipole, a state must do more than flaunt its military and economic in the face of its rivals. Institutions and norms must be set up to legitimize the unipole's actions. The AIIB is a perfect example in illustrating China's quest for legitimacy as a major player on the global stage. Once the social mechanisms within the AIIB such as China's veto power are further examined, one can understand better on the bigger role that the bank serves to China's quest for regional dominance.

\footnotetext{
${ }^{42}$ Nancy Birdsall and Scott Morris, "Five Innovations at the AIIB," Center for Global Development. 25 May 2017, https://www.cgdev.org/blog/five-innovations-aiib

${ }^{43}$ Martha Finnemore, “Legitimacy, Hypocrisy, and the Social Structure of Unipolarity: Why Being a Unipole Isn’t All It's Cracked Up to Be," (2009): 74.

${ }^{44}$ Evelyn Goh, The Struggle for Order: Hegemony, Hierarchy, and Transition in Post-Cold War East Asia, (Oxford, Oxford University Press, 2013), 56.

${ }^{45}$ Edward White and John Reed, "China-backed AIIB Leaves Door Open to Lending To Myanmar's Junta," Financial Times, 2 June 2021, https://www.ft.com/content/cd39eba0-6bfb-4c5e-b68d-bfd00c2d7801

${ }^{46}$ Ibid.
} 
The growth of the membership of AIIB in Africa is another indicator of China's ambitions to expand its economic influence to multiple continents. In October this year, Nigeria became the investment bank's $20^{\text {th }}$ African member. ${ }^{47}$ This development is the latest chapter of AIIB strengthening its presence outside Asia, the region that, if solely looking at the name of the bank, as well as the usual modus operandi of other regional development banks ${ }^{48}$, is certainly interesting as it raises questions regarding the increasing African reliance on Chinese economic aid via its institutions. There are certainly attractive benefits of joining the AIIB. To assist states in developing their infrastructure via projects, the interest rates for loans offered by the AIIB are similar to the other MDBs and are much cheaper than those from the private sector. ${ }^{49}$ Another added benefit of joining that puts the AIIB ahead of, for example, the African Development Bank (AfDB), is the opportunity for the African states to tap into the potential of the Chinese and Asian markets by linking their markets to theirs. As one of the AIIB's main goals is cross-border and cross-continental connectivity, procuring loans to have a port built from the AIIB would be relatively easy. ${ }^{50}$ In addition, the African Continental Free Trade Agreement (AFCFTA), will accelerate this connectivity process, with enhancing the competitiveness of African states in the global market as one of its major objectives. ${ }^{51}$ Rwanda, a Least Developed Country (LDC) according to the United Nations, only joined in 2020 but has already secured a $\$ 100$ million loan from AIIB to start working on internet connectivity projects all across the country, with further funding coming from the World Bank and Rwandan government itself. ${ }^{52}$ Quick results in terms of obtaining the loans to develop one's state should attract more African states especially those classified as LDCs to also pivot towards AIIB in obtaining funds whose loan repayment conditions are not as burdensome as those from other MDBs and private sector sources. Egypt is another example of an African state which has taken advantage of the benefits on the offer from joining the AIIB. Since joining, the North African state has obtained fundings for three major infrastructure projects - one for solar energy, one for rural sanitation and one for domestic infrastructure - all of which are financed by AIIB. ${ }^{53}$ Being one of the earliest to join the continent in 2017, Egypt has obtained over $\$ 500$ million in loans, which is a productive return on their $\$ 650.5$ million capital contribution to the investment bank..$^{54}$

The continued cooperation between Egypt and the China-led AIIB indicates an increasing shift towards China instead of the U.S. and the West by African countries. This development is significant when one considers that Egypt has long been an important ally to the U.S. in the Middle East and North African region. As the U.S., under Donald Trump's administration, dabbled with isolationist and anti-liberal order rhetoric, China was more than happy to provide a stable system and mechanism to accommodate developing and the least developed countries and provide them with avenues to pursue development projects amidst the uncertainties caused by the statements and actions of the

\footnotetext{
${ }^{47}$ Asian infrastructure Investment Bank (AIIB), “AIIB's Membership in Africa Grows as Nigeria Joins the Bank," 27 October 2021, https://www.aiib.org/en/news-events/news/2021/AIIB-s-Membership-in-Africa-Grows-as-Nigeria-Joinsthe-Bank.html\#: :text=AIIB\%20now\%20has\%2020\%20approved,46\%20percent\%20of\%20Africa's\%20population.

${ }^{48}$ Hannah Ryder, "Why Did the Asian Infrastructure Investment Bank Make a Loan to Rwanda?" The Diplomat, 3 August 2021, https://thediplomat.com/2021/08/why-did-the-asian-infrastructure-investment-bank-make-a-loan-to-rwanda/

${ }^{49}$ Cyril Prinsloo, “AIIB Membership for African Countries: Drawcards and Drawbacks," Global Policy 10, no. 4, (2019): 625.

${ }^{50}$ Carla P. Freeman, "Constructive Engagement? The US and the AIIB," Global Policy 10, no. 4, (2019): 667-676.

${ }^{51}$ Garth L. le Pere, "US-China Geoeconomics Tensions: Implications for the African Continental Free Trade Area," Asian Perspective 45, no. 1, (2021): 148.

${ }^{52}$ Cobus Van Staden et al., "In the Driver's Seat? African Agency and Chinese Power at FOCAC, the AU and the BRI," African Perspectives Occasional Paper 286, South African Institute of International Affairs (SAIIA), 21 September 2018, https://media.africaportal.org/documents/saia_sop_286_Van-Staden-Alden-Wu_20180921.pdf

${ }^{53}$ Chris Alden et al., "China-Driven Port Development: Lessons from Kenya and Malaysia," SAIIA Policy Briefing No. 257, South African Institute of International Affairs (SAIIA), 14 December 2021, https://saiia.org.za/research/china-drivenport-development-lessons-from-kenya-and-malaysia/

${ }^{54}$ Andrew Mold, "Modelling the Economic Impact of the china Belt and Road Initiative on East Africa," United Economic Commission for Africa (UNECA), 15 June 2018, https://www.gtap.agecon.purdue.edu/resources/download/9119.pdf
} 
former President which suggested U.S.'s commitment towards the continued development of the Global South had waned. Judging from the engagement from African states and beyond, it appears that the legitimacy of the AIIB is at a high point, showing that it has been successful in its quest not only to conduct its mission statement, but also to establish itself as a viable institutional partner to assist in the Global South's development.

This quest has not been without its obstacles, however. In the years following AIIB's establishment, China's own reputation and legitimacy on the international stage have taken some major blows. Condemnation of its "re-education" policy towards Uighurs, its crackdown on pro-democracy protesters in Hong Kong, its unwillingness to be fully transparent regarding the origins of COVID-19, and perceived naval aggression in the South China Sea have put China in a very tricky situation with regard to its custodianship of AIIB. Recently, the AIIB, which mostly avoided accusations similar to those faced by China, has been criticized for a lack of transparency in their projects. Communities whose livelihoods were negatively affected by a project in Mandalika, Indonesia had no recourse to hold any party responsible because the investment bank was unwilling to release audits regarding said project to the public. ${ }^{55}$ The aforementioned willingness to continue lending to Myanmar's military junta could also lead to accusations of propping up a repressive and undemocratic regime which engages in violence against its own citizens. Judging from how anti-China sentiments are being proliferated on the international stage, the systemic legitimacy of AIIB may soon be decreasing owing to a more hawkish and wary Western alliance.

A Western alliance has indeed taken shape in the form of the AUKUS trilateral security pact between Australia, the United Kingdom, and the United States. The pact will see the U.S. and the U.K. assisting Australia's in obtaining nuclear-powered submarines, in addition to these three countries cooperating on matters relating to artificial intelligence, cyber and additional undersea capabilities, among others. Australia's decision to join this pact has been described by former Prime Minister Tony Abbott as a response to the "great strategic challenge of our time, which is obviously China." 56 Seen as a reaction to China's growing influence in Asia-Pacific region economically, as well as militarily, the pact has elicited strong reactions and rebukes from Beijing's foreign ministry spokesmen. ${ }^{57}$ Calling it "extremely irresponsible" and "narrow-minded", one official spokesman accused the Western allies of having a "Cold War" mentality with nuclear-powered weaponry being front and centre of this pact. ${ }^{58}$ This opinion was echoed by President Xi himself, who reiterated his country's position on AUKUS, in virtual meeting with his American counterpart, Joe Biden. ${ }^{59}$

Australia's forming of AUKUS was the latest development in year-long period of unprecedented tension with China. The worsening of the relations was prompted by Australia via its Prime Minister, Scott Morrison renewing calls for a fresh investigation into the origins of COVID-19 virus. ${ }^{60}$ Several issues have complicated the relationship, stemming from the allegations in 2017 by Australian Security Intelligence Organisation that there was Chinese interference in local politics in

\footnotetext{
55 Korinna Horta and Wawa Wang, "The AIIB Fails on Public Access to Information," Center for Strategic and International Studies (CSIS), 20 September 2021, https://reconasia.csis.org/the-aiib-fails-on-public-access-to-information/ 56 Stephanie Dalzell, "China Condemns AUKUS Pact, Tony Abbott flags a 'Common Danger', Kevin Rudd urges Caution," $A B C$ News, 16 September 2021, https://www.abc.net.au/news/2021-09-16/aukus-china-foreign-ministry-condemnsagreement-abbott-rudd/100468900

${ }^{57}$ Shintaro Hamanaka, “Insights to Great Powers' Desire to Establish Institutions: Comparison of ADB, AMF, AMRO and AIIB,” Global Policy 7, no. 2, (2016): 283. (288-292)

${ }^{58}$ Francois Heisbourg, "Euro-Atlantic DSecurity and the China Nexus," Survival 63, no. 6, (2021): 46. (45-62)

${ }^{59}$ Michael Beckley and Hal Brands, "The End of China's Rise: Beijing Out of Time to Remake the World," Foreign Affairs, 1 October 2021, https://www.foreignaffairs.com/articles/china/2021-10-01/end-chinas-rise

${ }^{60}$ Beyza Unal et al., "Is the AUKUS Alliance Meaningful or Merely Provocation?," Chatham House Royal Institute of International Affairs, 16 September 2021, https://www.chathamhouse.org/2021/09/aukus-alliance-meaningful-or-merelyprovocation
} 
the form of donations by Chinese businessmen to Australian politicians. ${ }^{61}$ Then, the Prime Minister, Malcolm Turnbull, although denying that it was in response to China, helped pass new laws in parliament to curb foreign interference, which Beijing did not like. ${ }^{62}$ Australia would then openly ban Huawei from operating in the country's $5 \mathrm{G}$ network the following year citing concerns for national security. ${ }^{63}$

The above examples regarding AUKUS, and Australia are just two among the many challenges to China's - and by extension, AIIB's - legitimacy. Its policy of assimilating Uighurs ethnic group into wider Chinese society - at times coercive and forceful and devalues the Uighur culture and religion - has already been designated as a genocide by the United States, legislatures in Canada, the United Kingdom, the Netherlands, and Lithuania. "Delegitimisation" could happen further to the AIIB as its founding state and patron, China, is increasingly having its authority challenged as a viable alternative to help one's state develop and as a trustworthy ally.

\section{CONCLUSION}

In viewing China's pursuit of global legitimacy via AIIB, one must consider the current situation, with questions of aggression in international waters, ethnic erasure of one of their minority groups, their unwillingness to be transparent during crucial periods during the outbreak of COVID-19 pandemic, and accusations of meddling in other countries' decision-making process all contribute to an overall decrease in their legitimacy. ${ }^{64}$ The countries currently challenging Chinese authority are ones that are powerful enough to sway the hearts and minds of the Global South to abandon the AIIB project alongside other Chinese-led initiatives.

\section{ACKNOWLEDGEMENT}

The author would like to show his gratitude to WIJEAS' anonymous reviewers and their constructive feedback in improving the quality of the manuscript. He is also immensely grateful for their comments on earlier versions of the draft. No potential conflict of interest was reported. This research received no specific grant from any funding agency in the public, commercial or not-for-profit sectors.

\footnotetext{
${ }^{61}$ Michito Tsuruoka, “AUKUS, Japan and the iNDO pacififc: Strategic Rationales and Challenges,” Policy Briefs No. 51, Global Governance Programme, EU-Asia Project, European University Institute, Cadmus, European University Institute Research Repository, 12 November 2021, https://hdl.handle.net/1814/72960

${ }^{62}$ Faisal Ahmed and Alexandre Lambert, The Belt and Road Initiative: Geopolitical and Geoeconomics Aspects, (London, Routledge, 2022), 87.

${ }^{63}$ David Brophy, China Panic: Australia's Alternative to Paranoia and Pandering, (Victoria, La Trobe University Press, 2021), 23

${ }^{64}$ Anders Uhlin, "Legitimacy Struggles in Global Governance: Legitimation and Delegitimation of the Asian Infrastructure Investment Bank," SAGE Open 9, no. 3, (2019): 5.
} 


\section{REFERENCES}

Ahmed, Faisal, and Alexandre Lambert, The Belt and Road Initiative: Geopolitical and Geoeconomics Aspects, (London, Routledge, 2022).

Alden, Chris, Sergio Chichava, Lu Jiang, Bradley Murg, Guanie Lim and Yu-Shan Wu, "China-Driven Port Development: Lessons from Kenya and Malaysia," SAIIA Policy Briefing No. 257, South African Institute of International Affairs (SAIIA), 14 December 2021, https://saiia.org.za/research/china-driven-port-development-lessons-from-kenya-andmalaysia/

Asian infrastructure Investment Bank (AIIB), “AIIB's Membership in Africa Grows as Nigeria Joins the Bank," 27 October 2021, https://www.aiib.org/en/news-events/news/2021/AIIB-sMembership-in-Africa-Grows-as-Nigeria-Joins-the-

Bank.html\#: :text=AIIB\%20now\%20has\%2020\%20approved,46\%20percent\%20of\%20Afri ca's\%20population.

Beckley, Michael, and Hal Brands, "The End of China's Rise: Beijing Out of Time to Remake the World," Foreign Affairs, 1 October 2021, https://www.foreignaffairs.com/articles/china/202110-01/end-chinas-rise

Berkofsky, Axel, "The Chinese Dream and Chinese Foreign and Security Policies: Rosy Rhetoric versus Harsh Realities," Asia-Pacific Review 23, no. 2, (2016): 109-128.

Birdsall, Nancy, and Scott Morris, "Five Innovations at the AIIB," Center for Global Development. 25 May 2017, https://www.cgdev.org/blog/five-innovations-aiib

Brophy, David, China Panic: Australia 's Alternative to Paranoia and Pandering, (Victoria, La Trobe University Press, 2021).

Byman, Daniel L., and Kenneth M. Pollack, "Let Us Now Praise Great Men: Bringing the Statesman Back In," International Security 25, no. 4, (2001): 107-146.

Checkel, Jeffrey T., "The Constructivist Turn in International Relations Theory," World Politics 50, no. 2, (1998): 324-348.

Dalzell, Stephanie, "China Condemns AUKUS Pact, Tony Abbott flags a 'Common Danger', Kevin Rudd urges Caution," ABC News, 16 September 2021, https://www.abc.net.au/news/2021-0916/aukus-china-foreign-ministry-condemns-agreement-abbott-rudd/100468900

Finnemore, Martha, "Legitimacy, Hypocrisy, and the Social Structure of Unipolarity: Why Being a Unipole Isn't All It's Cracked Up to Be,” World Politics 61, no. 1, (2009): 58-85.

Foot, Rosemary, "China and the Tiananmen Crisis of June 1989," in Steve Smith, Amelia Hadfield, and Tim Dunne, eds., Foreign Policy: Theories, Actors, Cases (3rd edition), (Oxford, Oxford University Press, 2017), 334-355.

Freeman, Carla P, "Constructive Engagement? The US and the AIIB," Global Policy 10, no. 4, (2019): 667-676.

Friedman, Steven, "The Forgotten Sovereign: Citizens, States and Foreign Policy in the South," in Maurice A. East and Justin Robertson eds., Diplomacy and Developing Nations: Post-Cold War Foreign Policy-Making Structures and Processes, (3rd edition), (London, Routledge, 2012), 225-252.

Goh, Evelyn, The Struggle for Order: Hegemony, Hierarchy, and Transition in Post-Cold War East Asia, (Oxford, Oxford University Press, 2013).

Haggard, Stephan, "The Balance of Power, Globalization, and Democracy: International relations Theory in Asia," Journal of East Asian Studies 4, no. (2004): 1-38.

Hamanaka, Shintaro, "Insights to Great Powers' Desire to Establish Institutions: Comparison of ADB, AMF, AMRO and AIIB," Global Policy 7, no. 2, (2016): 288-292.

Hameiri, Shahar, and Lee Jones, "China Challenges Global Governance? Chinese International Development Finance and the AIIB," International Affairs 94, no. 3, (2018): 573-593.

Heisbourg, Francois, "Euro-Atlantic Security and the China Nexus," Survival 63, no. 6, (2021): 45-62. 
Horta, Korinna and Wawa Wang, "The AIIB Fails on Public Access to Information," Center for Strategic and International Studies (CSIS), 20 September 2021, https://reconasia.csis.org/theaiib-fails-on-public-access-to-information

Huang, Kristin, "China-Canada Ties to Get Frostier After Call to Leave AIIB, Analysts Say," South China Morning Post, 12 December 2019, https://ph.news.yahoo.com/china-canada-tiesfrostier-call-105718228.html

Johnson, Ian, "Xi Jinping and China's New Era of Glory," The New York Times, 13 October 2017, https://www.nytimes.com/2017/10/13/sunday-review/xi-jinping-china.html

Kang, David C., "Hierarchy, Balancing, and Empirical Puzzles in Asian International Relations," International Security 28, no. 3, (2003): 57-85.

Katada, Saori N., and Jessica Liao, "China and Japan in Pursuit of Infrastructure Investment Leadership in Asia: Competition or Convergence?," Global Governance 26, no. 3, (2020): 449472.

Lanteigne, Mark, Chinese Policy: An Introduction (4th edition), (London, Routledge, 2020).

Mold, Andrew, "Modelling the Economic Impact of the china Belt and Road Initiative on East Africa," United Economic Commission for Africa (UNECA), 15 June 2018, https://www.gtap.agecon.purdue.edu/resources/download/9119.pdf

Morris, Scott, and Mamoru Higashikokubaru, "Doing the Math on AIIB Governance," Center for Global Development, 2 July 2015, https://www.cgdev.org/blog/doing-math-aiib-governance

Ogden, Chris, A Dictionary of Politics, and International Relations in China, (Oxford, Oxford University Press, 2018).

Park, Miran, "China-led AIIB as a Gradual Modification of Asian Financial Order," Chinese Strategies to Launch New Financial Institution," Journal of International and Area Studies 24, no. 2, (2017): 57-76.

Pere, Garth L. le, "US-China Geoeconomics Tensions: Implications for the African Continental Free Trade Area," Asian Perspective 45, no. 1, (2021): 147-156.

Prinsloo, Cyrill, “AIIB Membership for African Countries: Drawcards and Drawbacks," Global Policy 10, no. 4, (2019):625-630.

Ren, Xiao, "China as an Institution-Builder: The Case of the AIIB," The Pacific Review 29, no. 3, (2016): 435-442.

Ryder, Hannah, "Why Did the Asian Infrastructure Investment Bank Make a Loan to Rwanda?" The Diplomat, 3 August 2021, https://thediplomat.com/2021/08/why-did-the-asian-infrastructureinvestment-bank-make-a-loan-to-rwanda/

Shirk, Susan, "The Domestic Context of Chinese Foreign Security Policies," in Sadia M. Pekkanen, John Ravenhill, and Rosemary Foot, eds., The Oxford Handbook of the International Relations of Asia, (Oxford, Oxford University Press, 2014), 391-410.

Stephan, Mathew D., and David Skidmore, "AIIB in the Liberal International order," Chinese Journal of International Politics 12, no. 1, (2019): 61-91.

Stevens, Friso M. S., "China's Long March to National Rejuvenation: Toward a Neo-Imperial Order in East Asia?," Asian Security 17, no. 1, (2021): 46-63.

Tsuruoka, Michito, “AUKUS, Japan and the Indo Pacific: Strategic Rationales and Challenges,” Policy Briefs No. 51, Global Governance Programme, EU-Asia Project, European University Institute, Cadmus, European University Institute Research Repository, 12 November 2021, https://hdl.handle.net/1814/72960

Uhlin, Anders, "Legitimacy Struggles in Global Governance: Legitimation and Delegitimation of the Asian Infrastructure Investment Bank," SAGE Open 9, no. 3, (2019): 1-14.

Unal, Beyza, Kerry Brown, Patricia Lewis and Yu Jie, "Is the AUKUS Alliance Meaningful or Merely Provocation?," Chatham House Royal Institute of International Affairs, 16 September 2021, https://www.chathamhouse.org/2021/09/aukus-alliance-meaningful-or-merely-provocation 
Van Staden, Cobus, Chris Alden and Yu-Shan Wu, "In the Driver's Seat? African Agency and Chinese Power at FOCAC, the AU and the BRI," African Perspectives Occasional Paper 286, South African Institute of International Affairs (SAIIA), 21 September 2018, https://media.africaportal.org/documents/saia_sop_286_Van-Staden-AldenWu_20180921.pdf

Waltz, Kenneth, Man, The State, And War, (New York, Columbia University Press, 1979).

Wang, Yu, "The Political Economy of Joining the AIIB," The Chinese Journal of International Politics, 11, no. 2, (2018): 105-130.

Wendt, Alexander, "Anarchy is What States Make of It: The Social Construction of Power Politics," International Organization 46, no. 2, (1992): 391-425.

White, Edward, and John Reed, "China-backed AIIB Leaves Door Open to Lending To Myanmar's Junta," Financial Times, 2 June 2021, https://www.ft.com/content/cd39eba0-6bfb-4c5e-b68dbfd00c2d7801

Wo-Lap Lam, Willy, "The Agenda of Xi Jinping in the Chinese Communist Party: Capable of Through Reform?” in Willy Wo-Lap Lam ed., Routledge Handbook of the Chinese Communist Party, (London, Routledge, 2018), 3-24.

Wohlforth, William C., "Unipolarity, Status Competition, and Great Power War," World Politics 61, no. 1, (2009): 28-57.

Zhu, Jiejin, "Is the AIIB a China-controlled Bank? China's Evolving Multilateralism in Three Dimensions (3D)," Global Policy 18, no. 4, (2019): 653-659. 